\title{
Integrated construction supervision as a tool to reduce the developer's risks when implementing new and redevelopment projects
}

\author{
Dmitriy Topchiy ${ }^{1, *}$ Anastasia Shatrova ${ }^{1}$ and Alexey Yurgaytis ${ }^{1}$ \\ ${ }^{1}$ Moscow State University of Civil Engineering, Yaroslavskoe shosse, 26, Moscow, 129337, Russia
}

\begin{abstract}
The article describes the importance of construction supervision by a Developer (EPCM Contractor) as an effective tool for reducing potential risks when implementing investment and construction projects. In general, the paper describes the practice of hiring construction supervisors, the need for an integrated, systemic approach to the work acceptance process. The proposed integrated verification supervision method includes Contractor's laboratory data confirmation in order to optimize and improve the control functions. The method was analyzed using existing statistical techniques. The paper suggests ways for determining quality and quantity characteristics of sampling (verification supervision) from the general totality (Contractor's initial supervision) while observing the representativeness condition.
\end{abstract}

\section{Introduction}

When implementing various investment projects in the Russian Federation, regardless of funding sources, a Developer is obligated to carry out construction supervision using its own resources or to get a specialist organization to do the job. In fact, a Developer, not being a specialist on industrial and civil construction, in accordance with the requirements of the Town Planning Code, has to authorize the specialized EPCM contractor's service (a legal entity or an individual) to perform control on its behalf of all construction and investment process, from preparation of detailed design documentation to final commissioning. It is in the interests of an EPCM contractor that the authors of this paper have decided to develop an integrated construction supervision technique, one that would allow the control function to be optimized and improved.

Customer construction control in the capital construction projects, including unique and technically complex projects, allows tracking the technological sequence of construction, the composition of technological operations, to control the volume and terms of primary inspection of construction products, materials and equipment by a General Contractor. Representatives of the technical supervision service and construction control in the implementation of control activities accept works actually performed by a General Contractor, check their compliance with regulations, technical regulations, results of engineering studies, requirements of GPZU and project instructions (stage "P" and "RD") .

\footnotetext{
* Corresponding author: angela-1309.m@yandex.ru
} 
The contractors are supplied with the executive documentation on works, which should confirm that the finished products comply with the parameters and regulatory requirements. In industrial construction, the Customer may reasonably doubt the correctness of the provided charts, quality documentation and test reports. We talk about potential and highly significant risks arising from the implementation of investment projects, which may well be made up for by the required scope of qualitative, timely referential construction supervision by the EPCM Contractor in terms of quantitative and qualitative indicators.

Customers of construction products in a number of foreign countries use the help of Construction control services in some form, despite the fact that it is not always required by law (see Table 1). Furthermore, modern legislation in the Russian Federation and globally does not oblige the Construction Supervision Service to carry out tool measurements, geodetic measurements, and, moreover, laboratory verification of construction in the course of its monitoring activities. Given that the construction supervision carried out by the Customer should include verification of correctness, completeness and compliance of results reporting, such compliance is impossible because of unclear studies and tests methods used at the site.

Table 1. Functioning of Customer Construction Supervision Service in foreign countries.

\begin{tabular}{|l|l|l|}
\hline No. & \multicolumn{1}{|c|}{ Country } & \multicolumn{1}{|c|}{$\begin{array}{c}\text { Short description of Customer construction supervision } \\
\text { approaches }\end{array}$} \\
\hline 1. & Russian Federation & Own or third-party construction supervision service \\
\hline 2. & Republic of Belarus & Own or third-party construction supervision service \\
\hline 3. & United Kingdom & $\begin{array}{l}\text { Written assurance of the General contractor on the application } \\
\text { of an effective products quality control system; assigning } \\
\text { person responsible for quality. } \\
\text { Self-certification system for contractors. }\end{array}$ \\
\hline 4. & Germany & $\begin{array}{l}\text { Quality assurance system Qualitatssicherungs system (QSS), } \\
\text { whose main principle is "to produce quality, not control it". }\end{array}$ \\
\hline 5. & Sweden & $\begin{array}{l}\text { Construction Supervision Service does not exist. } \\
\text { Third-party expert is involved to assess quality of the finished } \\
\text { construction products }\end{array}$ \\
\hline 6. & Georgia & Construction supervision by the Customer is voluntary \\
\hline 7. & New Zealand & Construction supervision by the Customer is voluntary \\
\hline 8. & USA & $\begin{array}{l}\text { Construction supervision by the Customer is voluntary. } \\
\text { Customer is responsible for the constructed objects for the } \\
\text { entire period of operation }\end{array}$ \\
\hline
\end{tabular}

In their works V.A. Kotlyarevsky and A.V. Zabegaev prove that accidents in buildings and structures are caused by critical defects combined with human errors in the design, manufacture, installation and operation. The probability of an error for each person involved in the construction is assessed and shown below (Table. 2). The greatest degree of probability of various errors subsequently affecting the safety of construction and finished product quality falls on the Contractor. The proposed method to minimize errors is to develop organizational and technological model of construction supervision, which allows evaluation and improvement of supervision procedures, estimation of various potential risks of the Customer when implementing the project and elimination of these risks using integrated verification construction supervision.

Table 2. Error probability by participants of construction, affecting the safety of the building and product quality.

\begin{tabular}{|l|c|c|}
\hline \multirow{2}{*}{ Event } & \multicolumn{2}{|c|}{ Probability of event } \\
\cline { 2 - 3 } & Western Europe & \multicolumn{1}{c|}{ Russia } \\
\hline Architect's error & 0.10 & not assessed \\
\hline
\end{tabular}




\begin{tabular}{|l|c|c|}
\hline Designer's error & 0.40 & 0.20 \\
\hline Contractor's error & 0.50 & $0.50 \ldots 0.60$ \\
\hline Supervisor's error & 0.10 & not assessed \\
\hline Operation-related error & 0.02 & $0.10 \ldots 0.15$ \\
\hline Overloading of structures & 0.02 & $\sim 0.05$ \\
\hline Weak material & 0.02 & $\sim 0.20$ \\
\hline
\end{tabular}

\section{Integrated verification construction supervision}

This is the reason why many EPCM contractors around the world, when performing construction supervision, sign contracts with accredited laboratories for obtaining testing data and determining the competence and integrity of laboratory control undertaken by contractors. On the other hand, regulatory documents do not define the nature of such control by the Customer (selective or whole), the controlled parameters or the required number of standard tests or measurement methods, the specific list of types of work required for laboratory control. To solve this issue, we offer to work out the methodological normative and technical base for Construction Supervision Service, taking into account the functions of the geodesic center and testing laboratory to validate the quality and quantity of materials, components and finished products for construction. Organizations performing construction supervision may conduct work in a number of directions simultaneously:

- Office work with the design and permitting documentation;

- Control over compliance with organizational and process parameters;

- Verification of conformity of the executed works to the design and estimate and operating documentation requirements, regulatory and technical legislative framework.

- Selective geodesic control and monitoring;

- Selective control of the mechanical and chemical characteristics of construction materials, products and structures at the input, operational and acceptance control stages. One of the advantages of such an organization is integrated provision of services and subsequent reduction of potential risks of the constructor arising from the decentralization of control functions of construction process participants (Customer and General contractor).

Lack of shared responsibility and "one stop shop" authority allows for quick and correct provision of information with regards to the scope and quality of construction processes, and timely and necessary organizational and technological decision-making based on the data obtained. The integrated approach theory of construction supervision as a strategy for the prevention of industrial and financial losses, which guarantees against the creation of unusable products and mitigates other risks, sets the task of verifying the results of different controlled parameters measurements of construction products carried out using approved measurement methods with a given degree of precision. This problem can be solved using statistical methods and tools.

When carrying out inspection audits by the Customer, assumingly, duplication of the continuous assessment of compliance to regulated values is not necessary. The assessment, according to current regulations, is performed by a General contractor. In the absence of provision of legal and technical support, it is possible to determine the necessary and sufficient amount of lab tests of construction control service using the methods of mathematical statistics. Such an approach will reduce the costs, the number of supervisors, the duration and the complexity of the control processes.

\section{Determination of quantitative and qualitative indicators of verification supervision}


Assume the final general totality including set of homogeneous facts of measurements of a controlled parameter of construction products performed in a laboratory of the General Contractor, allowing assessment and usage thereof in the executive documentation. Units (samples) or the results of measurement of products that have been selected for a specific purpose in this general totality will be called a selection or samples (selected elements).

Consider two metrology sampling compatibility characteristics: quality (selection of sampling method and selection of objects to the required part of the general totality) (Table 3 ) and quantitative (the sample size proper or, in other words, the required representative part of sampled totality).

Table 3. Sampling methods.

\begin{tabular}{|l|l|l|}
\hline No. & Methods of units sampling & Short description \\
\hline 1. & Random-number selection & $\begin{array}{l}\text { Uses random-number tables. } \\
\text { This method is not recommended for } \\
\text { finished construction products. }\end{array}$ \\
\hline 2. & Multi-stage selection & $\begin{array}{l}\text { Sample in several stages, the units in each stage } \\
\text { are selected randomly from the units selected in } \\
\text { the previous step. } \\
\text { This method is not recommended for finished } \\
\text { construction products. }\end{array}$ \\
\hline 3. & Blind selection & $\begin{array}{l}\text { Sampling includes product units randomly } \\
\text { chosen from various parts of the general totality } \\
\text { regardless of controller subjective assumptions } \\
\text { about the quality withdrawn unit. }\end{array}$ \\
\hline 4. & Systematic sampling & $\begin{array}{l}\text { Units are randomly selected after a certain time } \\
\text { period or after a certain number of products in } \\
\text { the stream. }\end{array}$ \\
\hline
\end{tabular}

The indicator of correctly selected samples and guarantor of successful verification control is representativeness - compliance of sample characteristics with the same in the general totality, a measure which allows one to make a conclusion with regards to the parent sample of which the representative samples were taken out using only a small data set.

When the sampling is done (Table 3), we perform calculation of the quantitative characteristics of the sample by attributes (Table 4) according to the sampling plan (Table 5) based on the level of acceptable quality (AQL) (Table 6), assuming that construction control of the General contractor was initially organized properly and can be switched to more stringent control in case the current procedure helps detect poorer quality or irrelevant control (see. Table 7).

A selective quality control plan is a specific control plan, which sets the sample size and the necessary criteria for acceptance (acceptance and rejection numbers).

Table 4. Forms of selective sampling plan used.

\begin{tabular}{|l|l|l|}
\hline No. & \multicolumn{1}{|c|}{$\begin{array}{c}\text { Forms of selective sampling } \\
\text { plan used }\end{array}$} & \multicolumn{1}{c|}{ Short description } \\
\hline 1. & & $\begin{array}{l}\text { A simpler form of statistical control unit where } \\
\text { the finished building product or unit volume of } \\
\text { material at acceptance inspection are classified } \\
\text { only as appropriate or inappropriate. The number } \\
\text { of mismatches for each type of products in } \\
\text { accordance with statutory requirements. }\end{array}$ \\
\hline 2. & By an alternative attribute & $\begin{array}{l}\text { The finished building product or unit volumes of } \\
\text { material at acceptance inspection are classified } \\
\text { based on measuring characteristics of quality of } \\
\text { each item in the sample. }\end{array}$ \\
\hline
\end{tabular}


Table 5. Forms of selective sampling plan used.

\begin{tabular}{|l|l|l|}
\hline No. & \multicolumn{1}{|c|}{$\begin{array}{c}\text { Forms of selective sampling plan } \\
\text { used }\end{array}$} & \multicolumn{1}{c|}{ Short description } \\
\hline 1. & $\begin{array}{l}\text { Single-stage sample plan (integer } \\
\text { acceptance number) }\end{array}$ & $\begin{array}{l}\text { The plan type is represented by three numbers: sample } \\
\text { size, acceptance number and rejection number }\end{array}$ \\
\hline 2. & Two-stage sampling plan & $\begin{array}{l}\text { If the quality of the first sample is of intermediate } \\
\text { character, the second sample is monitored }\end{array}$ \\
\hline 3. & Multi-stage sampling plan & Up to 7-sampling control steps \\
\hline 4. & $\begin{array}{l}\text { Plans with fractional acceptance } \\
\text { number }\end{array}$ & - \\
\hline 5. & Irregular plans & Sampling plan is not saved for all subsequent batches \\
\hline
\end{tabular}

Table 6. Quality level grading.

\begin{tabular}{|c|c|c|c|c|}
\hline No. & Name & $\begin{array}{l}\text { Commonly used } \\
\text { Latin-alphabet } \\
\text { designation of quality } \\
\text { indicator in } \\
\text { mathematical statistics }\end{array}$ & $\begin{array}{l}\text { Short } \\
\text { designation }\end{array}$ & $\begin{array}{l}\text { Product requirement } \\
\text { tightening gradient }\end{array}$ \\
\hline 1. & $\begin{array}{l}\text { Acceptance Quality } \\
\text { Level (Acceptance } \\
\text { Defect Limit) } \\
\text { Set in the } \\
\text { specifications for the } \\
\text { products. }\end{array}$ & $\begin{array}{l}\text { Acceptance Quality } \\
\text { Limit }\end{array}$ & AQL & \\
\hline 2. & $\begin{array}{ll}\text { Average } & \text { Outgoing } \\
\text { Quality } & \\
\end{array}$ & $\begin{array}{ll}\text { Average } & \text { Outgoing } \\
\text { Quality } & \\
\end{array}$ & AOQ & \\
\hline 3. & \begin{tabular}{l}
\multicolumn{2}{c}{ Average } \\
Outgoing Quality \\
Limit
\end{tabular} & \begin{tabular}{l}
\multicolumn{1}{c}{ Average } \\
Outgoing Quality \\
Limit
\end{tabular} & AOQL & \\
\hline 4. & $\begin{array}{lr}\text { Consumer's } & \text { Risk } \\
\text { Quality } & \text { (EPCM } \\
\text { Contractor) } & \\
\end{array}$ & $\begin{array}{ll}\text { Consumer's } & \text { Risk } \\
\text { Quality } & \end{array}$ & CRQ & \\
\hline 5. & $\begin{array}{ll}\begin{array}{l}\text { Producer's } \\
\text { Quality }\end{array} & \text { Risk } \\
\end{array}$ & $\begin{array}{ll}\begin{array}{l}\text { Producer's } \\
\text { Quality }\end{array} & \text { Risk } \\
\end{array}$ & PRQ & \\
\hline 6. & $\begin{array}{l}\text { Limiting Quality } \\
\text { (Non-Acceptance } \\
\text { Defect Limit) }\end{array}$ & Limiting Quality & LQ & \\
\hline
\end{tabular}

Table 7. Control type by responsibility degree.

\begin{tabular}{|l|l|l|}
\hline No. & \multicolumn{1}{|c|}{$\begin{array}{c}\text { Control type by } \\
\text { responsibility degree }\end{array}$} & \multicolumn{1}{c|}{ Short description } \\
\hline 1. & Light & $\begin{array}{l}\text { Use of a sampling plan with the sample volume } \\
\text { less than that for the normal type. } \\
\text { Product acceptance criteria comparable to the } \\
\text { normal type. }\end{array}$ \\
\hline 2. & Normal & $\begin{array}{l}\text { Use of a sampling plan with the quality level } \\
\text { ensuring the quality better than the acceptable } \\
\text { quality level. }\end{array}$ \\
\hline 3. & Stringent & $\begin{array}{l}\text { Use of a sampling plan with stronger acceptance } \\
\text { criteria compared to normal (where sampling } \\
\text { scope is concerned). }\end{array}$ \\
\hline
\end{tabular}


The acceptable quality level (AQL) is a quality level which, when considering continuous sequence of batches, lies at a threshold of average quality level (maximum allowable share of defective products is admissible quality level).

Let us take a single-stage sampling plan for the alternative method as the most simple. Although quantitative attribute calculations have several advantages, the selected method is fully justified in the particular experiment. Control type by responsibility - normal (the most common pattern, if there are no specific requirements to other terms of statistical analysis).

Determination of a quantitative characteristic of sample under laboratory verification test data produces the following result. Sampling volumes, i.e. in our case - the number of verification measurements to be undertaken in the laboratory of Customer's construction control service is calculated in accordance with homogeneous dimensions in General Contractor Laboratories, assumed as the general distribution of the set values (Table 8).

Table 8. Number of verification measurements (sample size).

\begin{tabular}{|l|l|c|l|}
\hline \multirow{2}{*}{ No. } & \multicolumn{2}{|l|}{$\begin{array}{l}\text { General distribution scope } \\
\text { (Number of measurements carried out in the } \\
\text { General Contractor construction laboratory of) }\end{array}$} & $\begin{array}{l}\text { Sample size } \\
\text { (Number of verification } \\
\text { measurements produced by the } \\
\text { Customer laboratory) }\end{array}$ \\
\hline 1. & From & To (inclusively) & 2 \\
\hline 2. & 9 & 15 & 3 \\
\hline 3. & 16 & 25 & 5 \\
\hline 4. & 26 & 50 & 8 \\
\hline 5. & 51 & 90 & 13 \\
\hline 6. & 91 & 150 & 20 \\
\hline 7. & 151 & 280 & 32 \\
\hline 8. & 281 & 500 & 50 \\
\hline 9. & 501 & 1,200 & 80 \\
\hline 10. & 1,201 & 3,200 & 125 \\
\hline 11. & 3,201 & 10,000 & 200 \\
\hline 12. & 10,001 & 35,000 & 315 \\
\hline 13. & 35,001 & 150,000 & 500 \\
\hline 14. & 150,001 & 500,000 & 800 \\
\hline 15. & 500,001 & & \\
\hline
\end{tabular}

\section{Conclusion}

Thus, laboratory control as part of an integrated construction supervision by the Customer allows reducing the risk of improper measurements during the design tests and input control of materials, equipment and semi-finished products, as well as avoiding incorrect registration of results in the executive documentation, which could lead to the finished construction products being accepted with defects or made of improper materials and semi-finished products. Verification sampling of the general totality of the measurements performed by approved method or complete centralization of complex control functions in the customer's hands can be a kind of additional barrier for error in terms of ensuring the accuracy, and sufficient correctness of the measurements, and virtually excluding corruption risks. These additions to the qualimetrical method of determining the quality of the finished construction products will significantly improve compliance requirements while creating the product in a timely manner.

\section{References}


1. An. Mottaeva, As. Mottaeva, Economy and Entrepreneurship 4-1(69-1), 1124-1129 (2016)

2. D.V. Topchiy, V.A. Skakalov, Scientific Review 03 (2017)

3. V.A. Kotlyarevsky, K.Ye. Kochetkov, A.A. Nosach, A.V. Zabegaev, Accidents and catastrophes. Prevention and response (ASV, 2003)

4. D.V. Topchiy, Technology and organization of construction production 1 (2014)

5. A.E. Bolotin, V.V. Bakayev, S.A. Vazhenin, Journal of Physical Education and Sport 15, 724-729 (2015), doi:10.7752/jpes.2015.04110

6. S.A. Assaf, S. Al-Hejji, International Journal of Project Management 24, 349-357 (2006)

7. A. Mills, Structural survey 19(5), 245-252 (2001)

8. E. Gehner, J. Halman, H. de Jonge, Risk management in the Dutch real estate development sector: a survey (In D., Amaratunga, 2006)

9. D. Chan, A. Chan, P. Lam, J. Chan, Construction Law Journal (CLJ) 26(5), 364-378 (2010)

10. A.R. Rumane, Management in Construction Projects (Taylor \& Francis Group, 2011)

11. B. Alexander, B. Vladislav, Journal of Physical Education and Sport 15, 362-364 (2015), doi:10.7752/jpes.2015.03054

12. B.F. Shirshikov, Organization, Planning and Construction Management (ASV, 2012)

13. R. Lakshmi, National Conference on Research Advances in Communication, Computation, Electrical Science and Structures (NCRACCESS-2015)

14. As. Mottaeva, D. Knyazev, Economy and entrepreneurship 10, 626 (2016)

15. V.A. Skakalov, Development of the organizational and technological model of building control (MGSU-2017) 